\title{
eGovernment Trends in the Web 2.0 Era and the Open Innovation Perspective: An Exploratory Field Study
}

\author{
Saïd Assar, Imed Boughzala, and Thierry Isckia \\ Telecom Business School \\ 9 rue C. Fourier 91011, France \\ \{said.assar, imed.boughzala, thierry.isckia\} @it-sudparis.eu
}

\begin{abstract}
Integrating Web 2.0 technologies in e-government opens up new opportunities for improving the quality of online public services and developing new ones, and can potentially contribute in achieving e-government strategic objectives. This paper presents and analyzes the result of an exploratory field study conducted recently with a group of e-government experts in France. Our objective is to identify e-government development trends, and to assess the transformation potential associated with Web 2.0 and Open Innovation (OI). We have adopted an enriched Delphi method, and used a GSS (Group Support System) to facilitate brainstorming and idea generation. Preliminary results are analyzed from two perspectives: Their contribution to e-government 2.0 and to open government, and their differences and complementarities with a recent governmental report on the future of public e-services in France. This work is a first step in a comprehensive research whose purpose is the study of public organizations' transformation and the emergence of the government 2.0 concept. It is a contribution to a better understanding of e-government future.
\end{abstract}

Keywords: Future directions in e-government, e-government 2.0, open innovation, open government, Web 2.0, field study.

\section{Introduction}

All around the world, significant advances are made in e-government. According to the UN e-Government Survey 2010 [1], citizens are benefiting from more advanced eservice delivery, better access to information, more efficient government management and improved interactions with governments. However, enormous challenges are still facing the development of e-government. Practitioners and researchers report many inherently complex situations requiring multidisciplinary perspective analysis and investigations, and the future of e-government is a recurrent question [2, 3, 4 and 5].

If we look at the EC benchmark's five-stage maturity model [6], it suggests that targetization is the next step in e-government development. The current objective is to provide online services that are customized to users' profiles and requirements, and to personalize the relation they have with public institutions. The emergence of Web 2.0 and the rise of social networks have indeed opened up new perspectives that challenge public institutions. These institutions are particularly attentive to the possibilities of taking advantages of these tools in the context of e-government. This trend towards 
web 2.0 usage in e-government is particularly visible in a recent report issued to the French government by a group of "Digital Experts" [8]. One of the main directions identified in this report for developing e-government is to improve interactions between government and users. The underlying idea is to involve users in the improvement of public services by allowing for example the user to assess governmental services online and to publish the results. The term e-government 2.0 points to the specific applications of social networks and Web 2.0 in the sphere of public services [7]. Many benefits are expected, such as a better match between public services and citizens' expectations, greater adoption of online services by citizens, or better control of costs and delays in the implementation of new services.

It is however the introduction of the Open Innovation (OI) concept [9, 10] in the governmental context which represents the most innovative and promising opportunity, both in terms of potential achievements and in terms of future research avenues to explore [11]. The concept of OI highlights the growing role of external sources of innovation, as opposed to relying only on internal resources within organizations [12]. It gives companies the ability to optimize their innovation process and to take advantage of new business opportunities. Transposed to the e-government context, OI could become a powerful way for public institutions to stimulate creativity, improve in-depth efficiency and quality of delivered services, and to build a new relationship with companies and citizens. The aforementioned Riester report [8] included some proposals for developing OI in public administrations, such as the creation of "Practice Labs" where users can participate more actively in the management, creation, development and evaluation of new public services; or the creation of a platform for service innovation ("State Lab") which allows third parties to develop innovative services using public data. OI is nevertheless a challenge for companies and for governments as well. It requires a profound change of attitude with respect to information- and knowledgesharing and dissemination, the questioning of governance modes, the mastering of new tools and technologies, etc.

Little academic work has focused explicitly on these issues so far, and the research presented in this paper is a contribution to fill this gap. The research questions may be formulated as follows: How Web 2.0 and OI can be used to change the current model of e-government towards a more social, open and participatory model? What are the most interesting and relevant topics and issues to be explored in order to get there?

In this exploratory study based on an enriched Delphi method, twenty French experts in e-government, from professional and academic spheres, participated in a half-day Expert Focus Group [13]. The objective was to reflect collectively on the development of e-government 2.0 and open government. This included understanding possibilities for applying Web 2.0 technologies and OI concept to e-government in France, identifying problems that may occur, and pointing to research topics related to the design, development and evaluation of new types of online services.

The rest of this paper is structured as follows: Section 2 present related works and describe briefly what Web 2.0 and OI are, and how they are actually perceived in an e-government context. Section 3 describes the research method that has been used, and how the Expert Focus Group has been conducted. Results are summarized and discussed in section 4. Section 5 contains concluding remarks and will sketch the limits of this work as well as its future perspectives. 


\section{Related Works}

New usages of information and knowledge-sharing have emerged with the advent of Web 2.0 technologies, giving rise to the Enterprise 2.0 concept [14, 15]. Enterprise 2.0 refers to "the use of Web 2.0, emergent social software platforms within companies, or between companies and their partners or customers" as defined initially by Andrew McAfee [16]. Used initially in the private arena, Web 2.0 technologies (e.g. blogs, wikis, $\mathrm{RSS}^{1}$, social networking platforms, folksonomy, podcasting, mashups, virtual worlds, etc.) are increasingly disseminated within the professional sphere, regardless of the type of organization or field of activities. These technologies - also called Social Media [17] - are user- (social) centered, userfriendly, intuitive and flexible. They are participatory and personalized with a dynamic content, and are generated by users themselves. Web 2.0 technologies are very useful for self-expression and mass participation, social networking, knowledge capitalization and co-creation, and skills and talents identification. They are a good opportunity for organizations to improve in the sharing of best practices, to boost social interactions and to encourage bottom-up and open innovation [10].

Coined by Chesbrough in 2003, the concept of OI is based on the premise that companies need to open up their innovation processes, combining both internal and external technologies to create business value [9]. Because companies can no longer rely exclusively on their own ideas and resources for fueling innovation, organizations should work with their customers, business partners and even their competitors according to specific organizational arrangements such as in- and outlicensing, selling and buying of Intellectual Property (IP), cross-licensing or spin-off ventures, in addition to traditional marketing. Opening up the innovation process requires the implementation of relational strategies in order to explore and exploit the business ecosystem in which companies operate. In [9], Chesbrough distinguishes inbound from outbound OI processes. Inbound innovation refers to an outside-in process through which the company will acquire resources in its environment to bring innovation to its current market. Instead, outbound innovation refers to an inside-out process through which the company will generate additional revenues and profits from selling in-house research outputs to other firms. OI can be described as a continuum between high and low degree of openness [18].

OI models can be developed both in the private and the public sector. Inbound and outbound innovation can be used by public agencies in order to develop new services for consumers and citizens, but also for the needs of public agencies themselves. While many public agencies develop specific applications for their own needs, they are also likely to use providers' turnkey applications to support their operations. Inbound innovation is therefore akin to a fairly common approach in the public sector. In contrast, outbound innovation is still very rare but is growing rapidly, as suggested by various initiatives related to e-government and/or Open Government [19]. On this point, the example of the District of Columbia (Washington, USA), is quite significant in term of outbound innovation. Since 2009, an $\mathrm{Apps}^{2}$ contest called Apps For Democracy makes it possible for independent developers, geeks, public and

\footnotetext{
${ }^{1}$ Really Simple Syndication.

${ }^{2}$ Applications Contest.
} 
private research centers to compete in order to create innovative online services that solve practical problems expressed by citizens through a social network. The purpose may be for example to identify the different cycling routes in the district, or to check the availability of a book in a public library. Public agencies within the District of Columbia provided developers with public data in order for them to build their applications. This ability to make high-value public data available to the public encourages participation and collaboration.

On emerging issues of e-government 2.0 and Open Government, research output is still quite limited. The views of U.S. President B. Obama in favor of open and collaborative government generated some scientific work: In [20] for example, the author offers an in-depth historical analysis of presidential directives' implications. In the same vein, the annual meeting of the Gov2.0 Summit has been bringing together since 2009 figures from the U.S. administration and some researchers to discuss experiments, problems and questions concerning e-Government 2.0 and Open Government implementation. Several governments around the world have conducted similar studies, notably in Australia [21]. Some recent academic publications tackle explicitly Open Government and the problems it raises: specific applications of the concept in the field of process management [11], the adoption of e-government 2.0 by citizens [22], or factors that promote openness, collaboration and participation [23].

\section{Research Method}

To conduct our exploratory study, we used a Delphi approach, enriched by the use of the thinkLets-based modeling proposed by Briggs et al. [24]. ThinkLets are packaged thinking activities (facilitation techniques) that create predictable, repeatable patterns of collaboration among people working toward a goal. They are used to streamline collaboration during brainstorming sessions, rapid decision-making, evaluation of strategic objectives, team building, creativity... [25]. Delphi studies are regularly used in information systems' studies when a consensus needs to be achieved among domain experts on a topic where ideas generation is required [26].

While Delphi studies are normally survey-based [27], we had the opportunity to use Group Support Systems (GSS) and a well-structured facilitation process. GSS is a suite of software tools designed to support collective problem solving, including the generation of ideas, reducing, organizing, and evaluating idea sets [28]. These tools facilitate the emergence and sharing of information among participants, and assist the facilitators in the control of the reflection process so that to converge to relevant proposals. Each team member in a GSS session uses a computer to submit ideas and votes to the group, to make selections, to organize ideas, or to write draft texts. Using GSS, all team members can contribute simultaneously, and may generate and evaluate ideas anonymously, while participating in well-structured deliberation processes [24]. The use of a GSS allowed us to collect in a bottom up fashion, extensive and wellorganized group collaboration results. It also served for the development of a synthesis report summarizing the results of the process, which is presented and discussed with all participants. 


\subsection{The Sample}

In December 2010, a number of organizations were invited to a research seminar at the authors' institution to discuss issues related to the use of Web 2.0 technologies and OI concept in the context of e-government, using electronic brainstorming. The participants were selected based on a diverse set of characteristics, including organizational type, area of activities, their profile, education, work experience, job, etc. Demographics of the study participants are provided in Table 1.

Table 1. Participants' demographic data

\begin{tabular}{|c|c|}
\hline Variable & Value \\
\hline Participants & $: 20$ \\
\hline $\begin{array}{l}\text { Organizations } \\
\text { represented }\end{array}$ & $: 16$ \\
\hline Largest Organization & $:>50,000$ \\
\hline Smallest Organization & $:<5$ \\
\hline Organization Types & $\begin{array}{l}: 8 \text { public-sector organizations, } 6 \text { private-sector } \\
\text { firms and } 2 \text { associations }\end{array}$ \\
\hline Area of activities & $\begin{array}{l}\text { : Ministry, Central Purchasing, Local government, } \\
\text { service firm, research center, telecom company, } \\
\text { University, Association, etc. }\end{array}$ \\
\hline Youngest Participant & $: 30-35$ \\
\hline Oldest Participant & : $56-59$ \\
\hline Average Age & $: 46$ \\
\hline Male Participants & $: 17$ \\
\hline Female Participants & $: 3$ \\
\hline Occupational profile & : 15 professionals and 5 academics \\
\hline Education Level & : MSc/MBA or PhD \\
\hline Education Type & $\begin{array}{l}\text { : Public or business Administration, political } \\
\text { science, computer science, law, geography, etc. }\end{array}$ \\
\hline $\begin{array}{l}\text { Most Years of Work } \\
\text { Experience }\end{array}$ & $: 15-20$ years \\
\hline $\begin{array}{l}\text { Least Years of Work } \\
\text { Experience }\end{array}$ & $:<4$ years \\
\hline $\begin{array}{l}\text { Average Years of Work } \\
\text { Experience }\end{array}$ & $: 10$ years \\
\hline Jobs & $\begin{array}{l}\text { : Top management, Innovation, R\&D, Research } \\
\text { and Forecasting, IT department, Project } \\
\text { management, higher education, etc. }\end{array}$ \\
\hline
\end{tabular}

\subsection{Issues and Themes Discussed}

Regarding the themes to be brainstormed, we relied on the results of the eGovernment RTD 2020 project [2]. The purpose of this collective work, carried out at European level, was to define future research topics in the e-government area. One of its main outcomes is a series of 13 research topics analyzed and classified by importance according to the perception of the expert group. For example, the two topics identified by the RTD 2020 project as the most important are: Data privacy \& personal identity, and Trust in e-government. 
After analyzing the RTD project's 13 proposed topics, we have summarized four key issues for the evolution of e-government:

- Performance and governance: This theme concerns the government operations and addresses issues such as effectiveness and efficiency, return on investment, value creation, public-private collaboration, etc. The brainstorming session on this theme was facilitated by a researcher ${ }^{3}$ in Strategic Management.

- Investment and infrastructure: This theme focuses on the technical, organizational and legal tools to be implemented to enable the development of services. It covers issues such as technical infrastructure development, authentication protocols, exchange formats, etc. The brainstorming session on this theme was facilitated by a researcher in Information Systems Engineering.

- Information quality: This theme relates to public information and its various dimensions such as its dissemination, confidentiality, traceability, security, but also personal digital identity, data privacy and protection, legal framework, etc. The brainstorming session on this theme was facilitated by a researcher in MIS.

- Roles and relationships: This theme deals with citizens' and companies' participation in content building and innovation in terms of services, stakeholders' accountability, copyright, etc. The brainstorming session on this theme was facilitated by a researcher in marketing and social networks.

\subsection{The Brainstorming Process}

The brainstorming process consisted of several activities in which the participants were asked to engage during a 180 minute period. A summarized agenda and research process follows:

- 60-minute introductions were necessary to (i) explain the expected outcomes of the brainstorming session by introducing the principles of Web 2.0 and OI; (ii) put into perspective some elements of the aforementioned Riester report [8]; (iii) present the thinkLets-based modeling method and explain the facilitated process for the brainstorming session through the GSS interface; and (iv) introduce and briefly explain the session's four themes of discussion (c.f. 3.2).

- Participants were then asked to anonymously generate proposals, ideas and suggestions around the four predefined themes of discussion (c.f. 3.2). They could submit as many proposals as they wished for each topic, according to their inspiration and expertise. A proposal is formulated around an objective, considered relevant when it is Specific (well defined), Measurable (with key success factors), Acceptable (attached to concrete actions), Realizable (feasible in the context) and can be defined in Time (SMART characteristics). During this process, each participant was able also to read and be inspired by the other participants' contributions. This is generally a source of emulation.

- Participants were then assigned to four subgroups and asked to reduce, clarify and organize collectively generated proposals around one of the four themes. Each subgroup was assisted in this task by a facilitator ${ }^{3}$. The goal is to converge on similar statements, remove non-related ones, and reword those insufficiently clear.

\footnotetext{
${ }^{3}$ Chosen among the researchers who conducted the study according to his/her research area.
} 
- Participants rejoined as a whole group, and each subgroup facilitator presented and explained to the group which proposals were selected for their respective theme.

- Participants were then asked to individually and anonymously rate the relevance of each proposal on a 10-point Likert-type scale, with '10' representing a very relevant statement and ' 1 ' a least relevant statement relating to both e-government 2.0 and open government.

- The voting scores were then presented to all participants in a raw format to stimulate a discussion of the results (proposal by proposal), and to allow the reformulation of proposals when necessary, to clarify ratings' standard deviations and so to create a collective consensus.

- Participants were finally asked to rate the consolidated proposals once again.

\section{Results and Discussion}

At the first stage of brainstorming, a total of 153 proposals were produced across the four themes. In accordance with the brainstorming process, they were reduced to a maximum of 10 proposals for each theme. The results presented in the following subsections have been treated twice. First, during the brainstorming process in the clarification, reduction, organization, evaluation and consensus stages; and second, after the brainstorming session, whereupon all proposals were verified and reformulated where necessary. In this last step, the focus was on two criteria: That there be no confusion of issues in the classification of proposals, and that the proposals are relevant to the field of e-government and OI.

After the brainstorming session, the final 29 selected proposals and their interpretations were sent out to all participants for final validation. Final results are presented in tables 2, 3, 4 and 5. For each theme, we indicate the average (Avg) voting score and the standard deviations (Std) of participants' responses for each proposal. These tables rank the proposals in order of increasing averages. The Cronbach alpha was calculated to assess the consistency of voting scores.

Table 2. Consolidated proposals for the $1^{\text {st }}$ theme: Performance and governance

\begin{tabular}{lcc}
\hline Proposal & Avg & Std \\
\hline 1.1 Federate digital identity to facilitate access to all services & 7.94 & 2.11 \\
1.2 Develop and organize access to public data & 7.81 & 1.91 \\
1.3 Develop and stimulate the creation of & 7.50 & 2.66 \\
$\begin{array}{l}\text { public/private/user/academic communities } \\
\text { 1.4 Improve communication between public and private actors } \\
\text { to better formalize the needs and to co-construct the solution }\end{array}$ & 7.50 & 2.94 \\
$\begin{array}{l}\text { 1.5 Develop flexible and scalable resources, on demand, } \\
\text { taking into account the specificities of the public sector }\end{array}$ & 7.38 & 2.50 \\
$\begin{array}{l}\text { 1.6 Develop a shared and transparent evaluation process to } \\
\text { measure ROI }\end{array}$ & 6.69 & 2.33 \\
\begin{tabular}{l} 
1.7 Develop a European collegial governance structure \\
\hline
\end{tabular} & 6.19 & 2.45 \\
\hline
\end{tabular}




\subsection{Theme 1: Performance and Governance}

For this theme, the expert group generated 55 initial proposals, out of which 7 have been elicited and are briefly presented below. The Cronbach alpha equals 0.87 (>0.7), indicating a certain homogeneity in the panel's responses relative to the understanding of these proposals.

\subsection{Theme 2: Investment and Infrastructure}

For this theme, the expert group generated 27 initial proposals, out of which 10 have been elicited and consolidated and are briefly presented below. The Cronbach alpha equals 0.91 ( $>0.7$ ), indicating a high homogeneity of responses relative to the understanding of these proposals by the panel members.

Table 3. Consolidated proposals for the $2^{\text {nd }}$ theme: Investment and infrastructure

\begin{tabular}{lcc}
\hline Proposal & Avg & Std \\
\hline $\begin{array}{l}\text { 2.1 Adapt public website ergonomics to accommodate user } \\
\text { profile (age, occupation, education level, etc.) and preferences }\end{array}$ & 7.5 & 2.71 \\
$\begin{array}{l}\text { 2.2 Impose the use of an (already existing) single digital } \\
\text { certificate format to ensure interoperability, relying mainly on }\end{array}$ & 7.44 & 2.00 \\
$\begin{array}{l}\text { a public consultation } \\
\text { 2.3 Move from unique or specific web portals for each public }\end{array}$ & 7.31 & 2.96 \\
$\begin{array}{l}\text { agency to fully customizable portals using widgets } \\
\text { 2.4 Provide digital spaces for consultation and exchange in } \\
\text { order to develop standards for the interoperability of public }\end{array}$ & 7.00 & 2.66 \\
documents, to be imposed by the government in the future & & \\
$\begin{array}{l}\text { 2.5 Adapt public computer systems to allow web 2.0 } \\
\text { architectures and usage }\end{array}$ & 7.06 & 2.41 \\
$\begin{array}{l}\text { 2.6 Identify and document public APIs }{ }^{4} \text {, evaluate them and } \\
\text { make them available in a shared repository }\end{array}$ & 6.81 & 2.74 \\
$\begin{array}{l}\text { 2.7 Before launching a new public call for tenders for a new } \\
\text { software development project, systematically use the } \\
\text { possibilities of Web 2.0 to check if such software development }\end{array}$ & 6.81 & 2.71 \\
has not already been made in another jurisdiction, or if similar \\
$\begin{array}{l}\text { or identical software applications are not already available on } \\
\text { the market }\end{array}$ & & \\
$\begin{array}{l}\text { 2.8 Promote the digital co-construction of government- local } \\
\text { community services using Web 2.0 technologies and through } \\
\text { an open and free service catalog }\end{array}$ & 6.75 & 3.00 \\
$\begin{array}{l}\text { 2.9 Develop and promote tools and spaces where users can } \\
\text { beta-test new public online services before they are made } \\
\text { available to the public }\end{array}$ & 6.75 & 3.13 \\
$\begin{array}{l}\text { 2.10 Change the legal framework to promote the development } \\
\text { of public services by third parties }\end{array}$ & 6.44 & 2.83 \\
\hline
\end{tabular}

${ }^{4}$ Application Programming Interface. 


\subsection{Theme 3: Quality of Information}

For this topic, 38 initial proposals were generated, out of which 7 have been elicited and consolidated. The Cronbach alpha equals $0.62(<0.7)$, indicating a relatively low homogeneity in the understanding of these proposals by the panel members. This probably expresses a certain lack of consensus on the meaning of the term "quality" itself and on the role of governments in defining and in assessing it.

Table 4. Consolidated proposals for the $3^{\text {rd }}$ theme: Quality of Information

\begin{tabular}{lcc}
\hline Proposal & Avg & Std \\
\hline $\begin{array}{l}\text { 3.1 Clearly distinguish between two different situations: one } \\
\text { where anonymity will prevail, and the other where it is }\end{array}$ & 7.81 & 1.91 \\
$\begin{array}{l}\text { essential for the user to have a reliable digital identity to } \\
\text { access more personalized services }\end{array}$ & & \\
$\begin{array}{l}\text { 3.2 Make policy makers aware of the necessity of } \\
\text { communicating about new Web 2.0 tools which are available }\end{array}$ & 7.56 & 2.16 \\
$\begin{array}{l}\text { to users, taking into account different behaviors } \\
\text { 3.3 Identify legal shortcomings and make legislative proposals }\end{array}$ & 7.44 & 2.00 \\
$\begin{array}{l}\text { 3.4 Encourage user contributions to the quality of information, } \\
\text { and describe these contributions }\end{array}$ & 7.38 & 2.55 \\
$\begin{array}{l}\text { 3.5 Improve the general knowledge of legal texts to better } \\
\text { identify the rights and duties of each player }\end{array}$ & 7.19 & 1.76 \\
$\begin{array}{l}\text { 3.6 Propose an experimental protocol (technical and legal) to } \\
\text { open public data while ensuring its quality }\end{array}$ & 6.94 & 2.32 \\
$\begin{array}{l}\text { 3.7 Explore the opportunity of establishing an official e- } \\
\text { government certification to guarantee information quality }\end{array}$ & 6.81 & 3.37 \\
\hline
\end{tabular}

\subsection{Theme 4: Roles and Relationships}

For this theme, the expert group generated 33 initial proposals, out of 5 which have been elicited and consolidated and are briefly presented below. The Cronbach alpha equals $0.94(>0.7)$, indicating a high homogeneity in responses relative to the understanding of these proposals by the panel members.

Table 5. Consolidated proposals for $4^{\text {th }}$ theme: Roles and relationships

\begin{tabular}{lcc}
\hline Proposal & Avg & Std \\
\hline $\begin{array}{l}\text { 4.1 Give users the means to evaluate/assess and judge the } \\
\text { quality of e-government services }\end{array}$ & 7.94 & 2.57 \\
$\begin{array}{l}\text { 4.2 Develop support and geographic/community mediation } \\
\text { services for users experiencing difficulties }\end{array}$ & 7.75 & 2.41 \\
$\begin{array}{l}\text { 4.3 Promote the convergence of practices by adapting to } \\
\text { media, new technologies and to public/business usage }\end{array}$ & 7.69 & 2.44 \\
$\begin{array}{l}\text { 4.4 Promote e-government as furthering social cohesion and } \\
\text { service development (collaboration with non-profits, R\&D } \\
\text { with companies, etc.) }\end{array}$ & 7.63 & 2.31 \\
$\begin{array}{l}\text { 4.5 Establish a single point of contact, a harmonized HCI, and } \\
\text { a single information file with tracking and traceability for } \\
\text { each citizen }\end{array}$ & 7.56 & 2.99 \\
\hline
\end{tabular}




\subsection{Discussion}

We have analyzed the results according to two points of views: The first is the direct contribution of proposals in answering the research questions (c.f. section 1), and the second is to examine the 29 proposals in light of the aforementioned Riester report delivered to the French government by the "Digital Experts" group [8].

For the first point of view, although all proposals concern the development of egovernment, not all of them are directly related to Web 2.0 and to OI. The proportion is however very significant, almost $50 \%$ (for sake of space, these 14 proposals are listed below ${ }^{5}$ ). This suggests that there is a high level of awareness in the expert panel concerning their impact on e-government, and this impact is perceived as an important opportunity for developing the quality, the extent and ultimately the nature of online public services.

For the second point of view, the 29 proposals confirm, complement and extend the Riester report's recommendations. In this official report published in February 2010, 25 initiatives were proposed (grouped into 3 categories and 7 subcategories), and 9 key success factors were suggested for sustaining a successful strategy of digital services. By cross-analyzing the expert panel proposals with report's recommendations, we have classified our proposals into three categories:

- The first category consists of 10 proposals which are similar and/or complementary to those made in the Riester report. They are initiatives and actions to be developed (for sake of space, these proposals are listed below ${ }^{6}$ ).

- The second category consists of 10 proposals which describe necessary factors for the development of government 2.0 and open government. While the success factors mentioned in the Riester report are general order recommendations, the proposals of our panel are much more precise and deal with specific problems. They are an interesting complement to success factors mentioned in the Riester report. They concern the following issues: Availability of public data to third parties (proposal 1.2), interoperability (proposals 2.2, 2.4, 2.5, 2.6), juridical aspects related to web 2.0 usage (proposals $2.10,3.5$ ), better communication and dialogue between public organizations (proposals 1.4, 3.2), adequate technical infrastructures (proposal 1.5).

- The third category is a collection of 9 proposals which cannot be correlated with the Riester report. They concern the resolutions of specific problems and the development of new services: Development of communities of practice (proposal 1.3), websites personalization (proposal 2.1), better public governance and higher level of transparency (proposals 1.6, 1.7, 2.7), optimization of identity management usages (proposal 3.1), enhancing the juridical environment (proposal 3.3), universal accessibility to all citizens and digital divide (proposals 4.2, 4.4).

\footnotetext{
${ }^{5}$ Proposals $\mathrm{n}^{\circ} 1.3,1.4,2.8,2.10,3.4,3.6,4.1,4.2$ are related to open innovation; and proposals $\mathrm{n}^{\circ} 1.2,1.3,2.5,2.6,2.9,3.2$ are related to web 2.0.

${ }^{6}$ Proposals which are complementary to those in the Riester report: proposals $n^{\circ} 1.1,2.3,2.8$, $2.9,3.4,3.6,3.7,4.1,4.3,4.5$.
} 


\section{Conclusion and Perspectives}

Questions concerning the future of e-government are recurrent in researchers and practitioners communities. In this exploratory field study, we have analyzed the views of a panel of experts with regard to the opportunity of integrating open innovation concept and benefiting from Web 2.0 technologies to develop e-government. With the help of a GSS-type software tool, the experts were able to identify challenges and opportunities in a very short time (150 minutes), and out of 153 initial proposals, 29 were selected, discussed and scored.

The preliminary results' analysis provides clear answers to our initial research questions. Almost 50\% of the collected proposals are directly related to e-government 2.0 and to open innovation in e-government. Many of them are initiatives which will clearly help in changing the current model of e-government towards a more social, open and participatory model. Although some proposals are similar to those initially made in a similar prospective report recently mandated by the French government, our study highlighted new success factors and came up with many complementary suggestions for the development of new public services. Important success factors unmentioned in the report - deal with issues such as open data availability, enhancing the juridical environment, or the interoperability of documents and standardization of electronic certificates. New service proposals embrace aspects such as reducing the digital divide, correlating e-government development with better transparency and better governance, or optimizing identity management.

This study represents the first stage of an ongoing research endeavor, and should be developed further - in particular through one or more detailed confirmatory studies to validate the results and to determine more precisely the nature and scope of concrete actions to be undertaken. However, due to the exploratory nature of this study, a limit must be considered: At this stage, this study does not lead to any final findings but rather to thoughts and insights. From this perspective, future work will combine qualitative and quantitative approaches. Several meetings are actually planned with the panel members and other experts in order to refine the proposals. Results of this study will be used for constructing a questionnaire, which will be administered to a large and significant sample of experts.

\section{References}

1. United Nations' Global E-Government Development Report, (2010), http: / / www2 . unpan.org/egovkb/global_reports/10report.htm

2. Codagnone, C., Wimmers, M.A.: Roadmapping eGovernment Research. eGovRTD2020 project consortium (2007), http: / / www. egovrtd2020 org /

3. Yildiz, M.: E-government research: Reviewing the literature, limitations and ways forward. Government Information Quarterly 24, 646-665 (2007)

4. Grönlund, ^.: Ten Years of E-Government: The 'End of History”' and New Beginning. In: Wimmer, M.A., Chappelet, J.-L., Janssen, M., Scholl, H.J. (eds.) EGOV 2010. LNCS, vol. 6228, pp. 13-24. Springer, Heidelberg (2010)

5. Assar, S., Boughzala, I., Boydens, I.: Practical Studies in E-Government: Best Practices from Around the World. Springer, New York (2010); ISBN 978-1441975324 
6. EC-European Commission: eGovernment Benchmark Survey 2009: Smarter, Faster, Better eGovernment, (2009),

http://ec.europa.eu/information_society/eeurope/i2010/ benchmarking/index_en.htm

7. Baumgarten, J., Chui, B.: e-Government. McKinsey Quarterly, (4) (2009), http://www.mckinseyquarterly.com/Business_Technology/ E-government_20_2408

8. Riester, F.: Enhancing the digital relation with the public user (in French). Report from the group of Digital Experts (2010),

http: //www.budget.gouv.fr/presse/dossiers_de_presse/ 100212 numerique.pdf

9. Chesbrough, H.: Open Innovation: The New Imperative for Creating And Profiting from Technology. Harvard Business Press, Cambridge (2003)

10. Chesbrough, H., Appleyard, M.: Open Innovation and Strategy. California Management Review 50(1), 57-76 (2007)

11. Niehaves, B.: Open Innovation and Public Sector Business Process Management: A MultiMethod Study. In: Proceedings of the $15^{\text {th }}$ Americas Conference on Information Systems (AMCIS), San Francisco, California, August 6-9 (2009)

12. Isckia, T., Lescop, D.: A critical analysis of open innovation fundamentals (in French). Revue Française de Gestion (accepted for publication, 2011)

13. Kitzinger, J.: Introducing focus groups. British Medical Journal 311, 299-302 (1995)

14. O'Reilly, T.: What Is Web 2.0: Design Patterns and Business Models for the Next Generation of Software. O'Reilly Media, Sebastopol (2008),

http://www.oreillynet.com/pub/a/oreilly/tim/news/2005/09/30/ what-is-web-20.html

15. Anderson, P.: What is Web 2.0? Ideas, Technologies and Implications for Education. JISC Technology and Standards Watch (2007), http://www.jisc.ac.uk/media/documents/techwatch/tsw0701b.pdf

16. McAfee, A.P.: Enterprise 2.0: The Dawn of Emergent Collaboration. Sloan Management Review 47(3), 21-28 (2006)

17. Kaplan, A.M., Haenlein, M.: Users of the world, unite! The challenges and opportunities of social media. Business Horizons 53(1), 59-68 (2010)

18. Allen, C.: Collective Invention. Journal of Economic Behavior and Organization (4), 1-24 (1983)

19. O'Reilly, T.: Government As A Platform. In: Lathrop, D., Ruma, L. (eds.) Open Government: Collaboration, Transparency, and Participation in Practice, pp. 11-38. O’Reilly Media, Sebastopol (2010)

20. McDermott, P.: Building Open Government. Government Information Quarterly 27, 401413 (2010)

21. Australian Government, Department of Finance and Deregulation: Engage: Getting on with Government 2.0. (2009), http: / / www. finance.gov.au/publications/gov20taskforcereport/

22. Nam, T.: New Ends, New Means, but Old Attitudes: Citizens' Views on Open Government and Government 2.0. In: Proceedings $44^{\text {th }}$ Hawaii Int. Conf. on System Sciences (HICSS), January 4-7 (2011)

23. Scholl, H.J., Luna-Reyes, L.: Uncovering Dynamics of Open Government, Transparency, Participation, and Collaboration. In: Proceedings $44^{\text {th }}$ Hawaii Int. Conf. on System Sciences (HICSS), January 4-7 (2011) 
24. Briggs, R.O., de Vreede, G.J., Nunamaker Jr., J.F.: Collaboration Engineering with ThinkLets to Pursue Sustained Success with Group Support Systems. Journal of Management Information Systems 19(4), 31-64 (2003)

25. Vreede, G.-J., de, B.R.O., Massey, A.P.: Collaboration Engineering: Foundations and Opportunities. Journal of the AIS 10, 121-137 (2009)

26. Keil, M., Tiwana, A., Bush, A.A.: Reconciling User and Project Manager Perceptions of IT Project Risk: A Delphi Study. Information Systems Journal 12, 103-119 (2002)

27. Schmidt, R., Lyytinen, K., Keil, M., Cule, P.: Identifying Software Project Risks: An International Delphi Study. Journal of MIS 17(4), 5-36 (2001)

28. Fjermestad, J., Hiltz, S.R.: An assessment of group support systems experimental research: methodology and results. Journal of MIS 15(3), 7-150 (1999) 